\title{
Poland in international migrations: the perspective of world systems theory
}

\begin{abstract}
This article presents the special status of Poland, namely as a country that both sends out and takes in large numbers of migrant workers. Drawing on the world systems theory, the role attributed to Poland is that of semiperiphery, which means a specific kind of suspension between the status of an immigration centre, resembling western Europe, and the status of a migration periphery, such as the one constituted by the eastern part of the continent. Poland continues to be viewed as peripheral by its own citizens who decide to emigrate and, at the same time, becomes an immigration sub-centre for migrants coming from less-developed countries. In this article, the distinctive features of the special position of Poland are discussed. The conclusions drawn are supported by empirical evidence, including data on migration flows and interviews both with Poles working abroad and foreigners employed in Poland.
\end{abstract}

Keywords

International labour migrations $\bullet$ immigration to Poland $\bullet$ centre-periphery division • Polish labour market

(C) University of Warsaw - Faculty of Geography and Regional Studies

\author{
Cezary Żołędowski C \\ Faculty of Political Science and International Studies, \\ University of Warsaw, Poland \\ e-mail: czoledowski@uw.edu.pl \\ Received: 27 August 2019 \\ Accepted: 7 February 2020
}

Introduction

The goal of this article is to demonstrate and discuss the specific character of Poland with regard to international migration. Poland tends to play a double role in this area: that of a country both sending and receiving labour migrants. Both phenomena are on a large scale - the considerable outflow of Polish citizens abroad is accompanied by an increasing inflow of foreigners to the domestic labour market. As a consequence, these two roles, ones treated as separate (if not opposing) by theoretical models of migration, have for some time existed hand in hand in the case of Poland. The role of Poland as a country of emigration has a long historical tradition, dating as far back as the middle of the seventeenth century. At that time, the Polish economy, still predominantly agrarian, collapsed and the country's significance in European international relations fell (eds Reddaway et al. 2016). This spurred an outflow of migration. On the other hand, Poland's parallel status as a country of immigration is a relatively new phenomenon, having emerged in the twentyfirst century. Consequently, in the past, and especially since the 1990s, studies of the role of Poland in international migration have assumed the perspective of a country sending migrants out). However, in response to the recently growing numbers of immigrants arriving and thereby gradually counterbalancing the trends caused by emigration, scholarly interest in the problems of immigration into Poland has been increasing.

From the broader perspective of international studies, the issues of the inflow of foreigners to Poland generally fit in the area of research on New Immigrant Destinations (NIDs) focusing on "examining new or emerging immigrant destinations and the implications of immigrant settlement in places that heretofore had no notable foreign-born populations" (Winders 2014, p 149). The parallel and complementary perspective of migrant research in Poland is that applied in the studies of the determinants of Poland's migration transformation, that is, the process through which a permanent surplus of immigration over emigration is reached. These studies embark on an analysis of the determinants of the gradual decline of emigration from Poland and attempt to forecast when this migration transformation will occur (Iglicka 2002; Okólski 2010).

In what follows, an attempt will be made to demonstrate the current status of Poland in relation to international migrations. To this end, we rely on statistical data covering the years after 2000 , as well as interviews carried out in 2017 , both with Poles working abroad and foreigners working in Poland. In interpreting the migration status of Poland, the perspective of the world systems theory has been applied. According to that concept, the migration role that should be attributed to Poland is that of a semi-periphery, which means a specific kind of suspension between the immigration centre, formed by western European countries, and the migration periphery, formed largely by areas on the eastern part of the continent. This status of Poland results from the intermediate character of its labour market with regard to income earned, the stability of employment and social security. These factors are all considered less attractive than those in the migration centre and, at the same time, more attractive than in the migration peripheries. The paper proceeds as follows. The next section discusses the centre-periphery theoretical perspective in the context of international migrations. The third section describes the trends in emigration from and immigration 
to Poland between 2001 and 2016 in the context of the centreperiphery concept. The fourth section touches upon the design of the survey of migrant workers, constituting the basis for additional empirical analyses. The fifth section discusses the results of the survey. The last section concludes the paper.

\section{Centre-periphery perspective in studies of international} migrations

The concept of a division into a centre (core) and the peripheral and semi-peripheral areas surrounding it is often applied in the area of studies of disproportions in social and economic development. In particular, it refers to unequal distribution of significance and the power to exert influence in particular areas. The concept has found application in studies of diverse spatial structures as well as various aspects of development. In the aggregate approach suggested by Wallerstein $(1974 ; 1984)$ in his world systems theory, the centre/periphery division refers to global and multidimensional diversity at the level of development, with special regard to economic interdependencies. It is also used in narrower studies, such as interdependencies of strictly political (Rokkan \& Urwin 1983) or cultural (Hannerz 1998) character.

In the area of migration studies, the theoretical perspective of the centre-periphery division is applied only incidentally. In reference to migrations within the $\mathrm{EU}$, it serves to emphasise the dichotomous division into western core and eastern peripheries. The latter are formed by "new" members, and the population flows between them and the former are considered to be an important factor reinforcing centre-periphery relations (Burrell 2009) as well as preserving the division (Ciupijus 2011). The perspective was implemented more consistently by Gois and Marques (2009) in a study demonstrating the semi-peripheral role of Portugal in the world migration system. The same authors pointed to arguments emphasising the usefulness of the categories derived from the world systems theory. The most important factor here is that they supplement the approach by monitoring the flows of people within the so-called migration systems. It requires a more precise definition of the functions fulfilled by particular regions. This is because assuming that the migration system is a multidimensional structure of links between countries sending out and receiving migrants, including (according to Kritz \& Zlotnik 1992, p 2) "a group of countries exchanging relatively large numbers of immigrants with each other", is not sufficient to describe the migration roles of those countries. As Gois and Marques (2009, p 27) point out, "we also need to conceive of a system as the interlinked product of differences between peripheries, cores and semi-peripheries that can only be understood in the context of one another. When we take this approach, the world systems theory emerges as an important theoretical instrument, since it allows us to assess the position of different countries within a system."

The potential adaptation of the centre-periphery concepts suggested by Wallerstein to the analysis of international migrations could be as follows:

- the migration centres are formed of countries most attractive to migrants, characterised by a constant positive net migration rate and - through their migration policies having a significant impact on the size and dynamics of world migrations;

- $\quad$ the migration peripheries are the areas with a very large potential for emigration, either realised or ready to be realised (under favourable conditions) and whose role in global migration movements is limited to the supply of the migrants either in response to demand in other countries or only in connection with their increasing openness to migration;

- the migration semi-peripheries are those countries which play the intermediate role in global migrations, experiencing both an inflow and outflow of migrants. In comparison with the migration centres, the possibility to influence the course of global migrations is limited.

The above characteristics underline the status application of categories adopted in the core-periphery approach in this study, similar to the aforementioned works of Hannerz or Rokkan and Urwin. At the same time, this does not exclude the possibility of a wider use of this perspective in international migration research, including in-depth analysis of relations between centres, semiperiphery and periphery. This requires, of course, expanding and clarifying the criteria for belonging to one of these three migration statuses.

The adaptation of the centre-periphery theory to the positioning of the countries in migration flows seems useful, especially due to the possibilities created by the use of the semiperipheral category. Irrespective of the criticism of that category, raising concerns with respect to the construction of the criteria of the semi-peripheral state, the category delivers a meaningful classification and explanatory advantages. Even if, in connection with the dynamics of the global socio-economic changes, the semi-peripheral status is not a permanent state of particular areas or countries, there can nevertheless be a specific kind of arena marked by the coexistence of divergent tendencies over a certain period of time (longer rather than shorter). Some of them can be unequivocally attributed to the centre, others are characteristics of the peripheries. This brings about divergent processes of development in the semi-peripheries.

Gois and Marques (2009) demonstrate convincingly the semi-peripheral migration status of Portugal as an aspect of a broader, semi-peripheral character of the country, resulting from its intermediate level of economic development and its role of intermediary between the "first" and the "third" world. An analogous role of the migration semi-periphery can be, for largely similar reasons, attributed to Poland, especially as analyses of other aspects of Polish society have oftentimes referred to the notion of the country's semi-peripheral position (ed Zarycki 2016).

\section{Dynamics of emigration from and immigration to Poland}

Over the period of, roughly, the last dozen years, official statistics have indicated the tendency for Poland's rate of permanent foreign migrations to approach zero. Accession to the EU in 2004 was the principal factor intensifying departures. The consequences of the accession and the gradual opening of the labour markets in the member states activated the emigration potential of Polish workers. An additional impulse to trigger emigration was created because of the within-country spatial disparities in the level of development (Stark, Micevska \& Mycielski 2009). Despite the rapid growth of more than a dozen urban centres that attract migrants both from other parts of the country and abroad, foreign emigration from peripheral areas remains substantial. Between 2009 and 2012, the number of registered departures decreased slightly, in response to the global financial crisis, to grow again when the economic conditions in western European countries improved. The main migration destinations for Poles remain unchanged, however, with the UK, Germany and the Benelux countries occupying top positions on the list of receiving countries (Janicka \& Kaczmarczyk 2016).

Unlike emigration from the country, permanent settlement immigration to Poland is characterised by a remarkably stable tendency (this includes permanent residence permits, naturalisation as well as - relatively few - repatriation visas, asylum and other forms of legal protection). The registered annual number of immigrants following Poland's accession to the EU remained largely stable. As a result of all the aforementioned tendencies, the net migration rate in 2016 turned out to be 


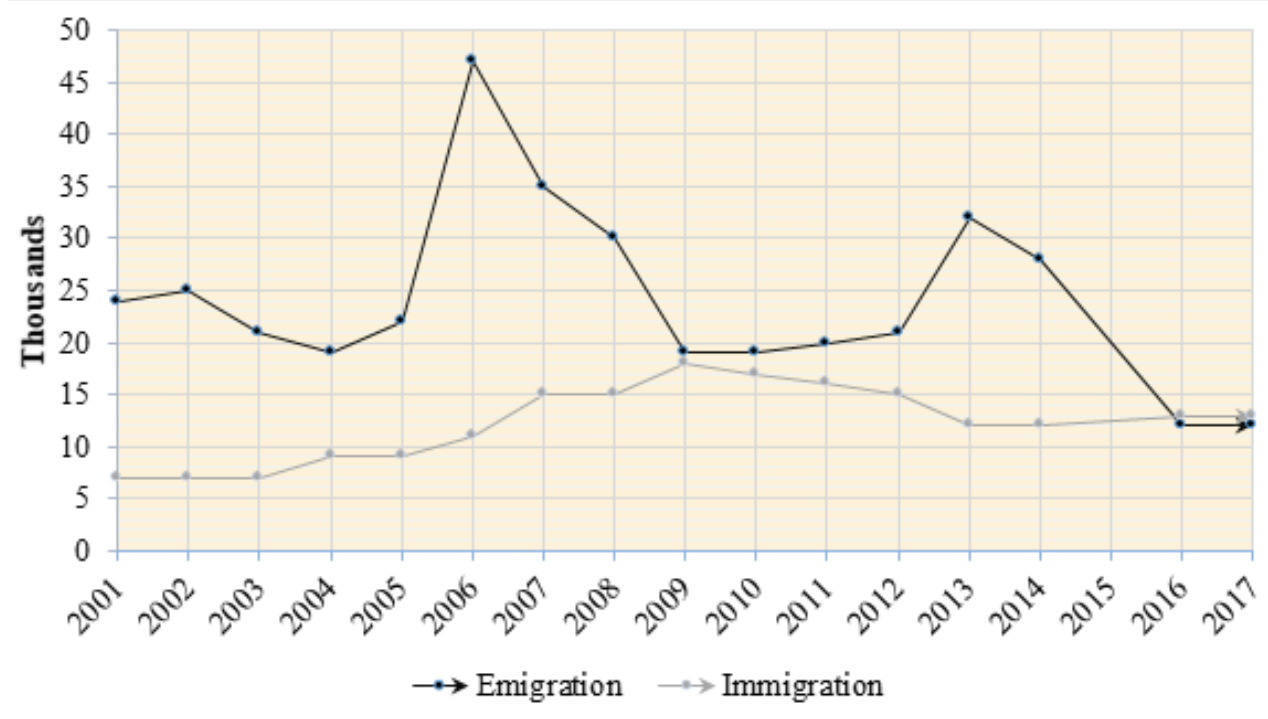

Figure 1. Emigration from and immigration to Poland, 2001-2017

Source: Own graphic based on data from Central Statistical Office of Poland.

marginally positive, the first outcome of this sort in the entire history of modern population statistics in Poland (Figure 1).

The net rate of long-term migration (over twelve months) is more advantageous for Poland. In 2016, the greatest difference (over 14,613 persons) between arrivals $(61,739)$ and departures $(47,126)$ was recorded. During the previous years, positive net rates of long-term migrations were also reported. In the period 2010-2012 it amounted to 15,164 persons altogether (Rocznik demograficzny 2017). Taking this kind of population flow into consideration (jointly with the short-term migrations - below twelve months) leads to a substantial revision of the stereotypical one-dimensional image of Poland solely as a country of emigration.

The aforementioned net rate of temporary migration, including short-term migration, shows high positive values. This type of migration distinguishes Poland from other EU countries; it marks the specific kind of migration associated with Poland. On the one hand, this results from the immigration policy implemented in Poland, focused on attracting temporary workers. On the other, it is an indicator of the semi-peripheral migration status of Poland - a country in which newcomers want to gain work and income rather than settle down for a longer time or for good (Górny \& Kaczmarczyk 2018). In more recent years, Poland's net rate of temporary migration is clearly positive. In 2016 , following an unprecedented increase in this kind of migration by as much as 61 per cent compared to the previous year, it turned out that Poland had become the world leader with respect to the number of temporary immigrants received (Figure 2).

A difficulty arising when interpreting the above statistical data is that the official data cannot take unregistered definitive emigration into account, a phenomenon whose prevalence may be substantial. At the end of 2017, the number of Poles recorded as staying abroad temporarily amounted to $2,540,000$ - a figure that is 25,000 higher than that reported in 2016 (Główny Urzad Statystyczny 2018). It would be difficult to forecast how many of those migrants will never return to Poland but the figures radically adjust the actual rate of foreign migrations. The number of foreigners in Poland is still relatively small, yet constantly increasing; growth has been particularly dramatic since 2015 . In that year, 108,300 persons were recorded ( 0.3 per cent of the population), which means a nearly threefold increase compared to 2004. 202,000 applications for residence permits were registered in 2017, a 33 per cent and a 71 per cent increase relative to 2016 and 2015, respectively. In addition, 10,000 persons from EU countries registered their stay. At the beginning of 2019, Polish official statistics recorded 372,000 foreigners who held valid documents entitling them to stay in Poland (Urząd ds. Cudzoziemców 2019). Most of those foreigners had a permit for temporary residence (up to three years). There are also foreigners with permits for permanent residence as well as those enjoying the right to stay as citizens of EU states. These data do not take into account the increasing number of naturalised people; 43,258 persons were granted Polish citizenship from 2005 to 2017. A large number of people staying in Poland with short-term work permits are not included in the above figures either.

The increasing importance of Poland as a place of immigration can also be inferred from statistics showing the share of foreign nationals on the Polish labour market. The number of foreigners interested in taking up legal employment in Poland is growing dramatically. In 2017, there were 267,136 applications for work permits submitted by residents of third countries and 235,626 of these were accepted. This was nearly twice as many as in the previous year (Ministerstwo Rodziny, Pracy i Polityki Społecznej 2018). In that same year, the counties' labour offices registered 1.8 million employer declarations of intent to hire a foreigner (an increase of 40 per cent compared to 2016), entitling them to work for six months within a period of twelve months. That legal instrument, introduced in 2007, is addressed to citizens of Armenia, Belarus, Georgia, Moldova, Russia and Ukraine. While initially almost all foreigners benefitting from it were employed in agriculture, construction and domestic services, more recent years have seen a rapid growth of this type of employment in other sectors of the economy (Tyrowicz, Kaczmarczyk \& Górny 2017). Yet, the number of migrants actually undertaking work on the basis of such declarations is significantly lower than the number of declarations issued, constituting between 60 and 65 per cent of the number of issued documents (Duszczyk \& Matuszczyk 2018). The growing scale of labour migration to Poland is also confirmed by the data concerning foreigners registered for pension insurance. At the end of March 2019 , there were 609,719 insured workers with citizenship other than Polish. This was six times as many as in 2013 and the vast 


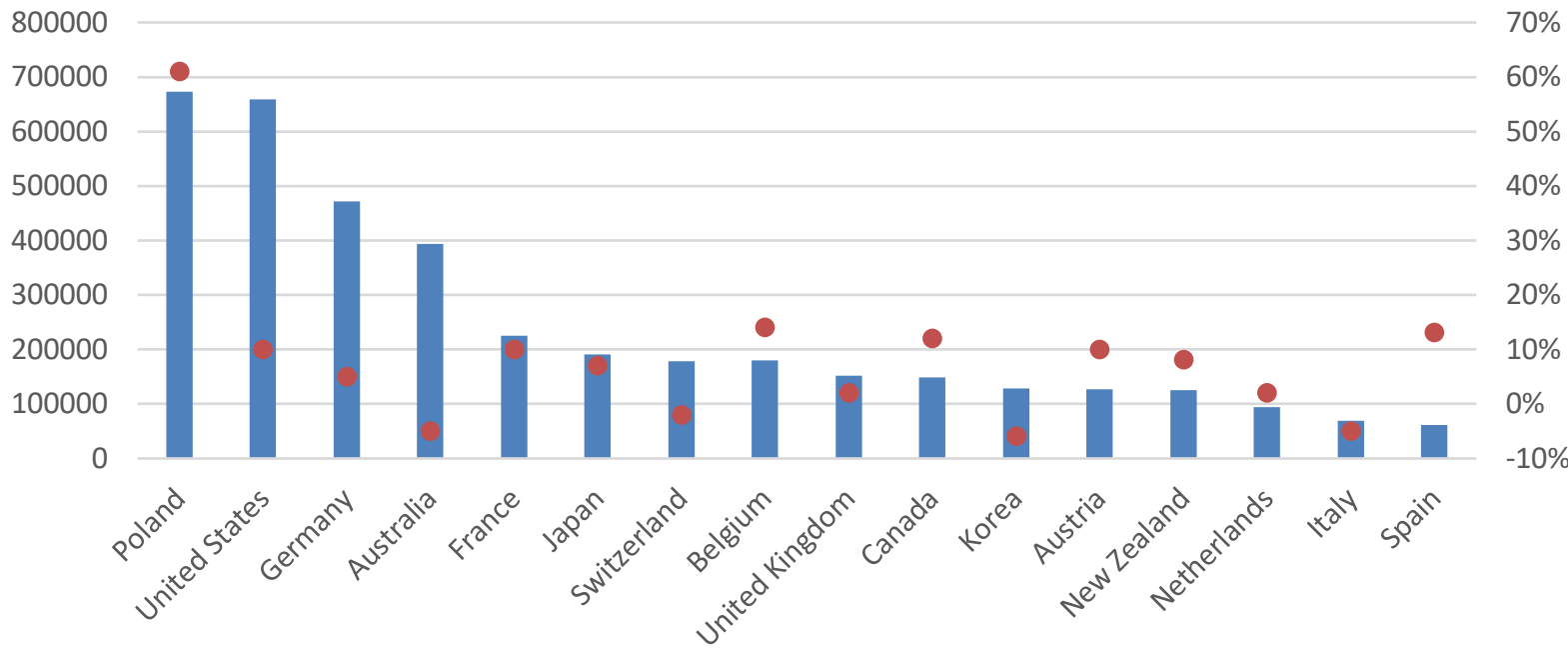

- Number of temporary labour immigrants (left axis) C Change in total 2016/15 (right axis)

Figure 2. Inflow of temporary labour migrants to leading countries, 2016 (and change in the total 2016/2015) Source: Own graphic based on International Migration Outlook 2018.

majority $(454,564)$ of those registered were Ukrainians (Zakład Ubezpieczeń Społecznych 2019). These data provide an incomplete picture of the legal employment of foreigners in the Polish economy (both holders of work permits and those employed under employer declarations). Among categories not included are farm workers, whose insurance status is distinct from that of those working in other sectors of the economy, and foreigners not covered by insurance at all.

Last but not least, a few remarks on the structure of the immigrants; countries of origin seem necessary here. Poland has so far been attractive primarily to labour migrants from Eastern Europe; the numbers of immigrants from Western Europe on the Polish labour market is rather miniscule. The vast majority of immigrants come from Ukraine (80 per cent of work permits, over 90 per cent of declarations of intent, 75 per cent of pension insurance). Other nationalities mainly include citizens of other countries that emerged following the dissolution of the USSR as well as citizens of various countries with restricted access to immigration centres. Thus, it is mainly the supply factor that determines the presence of immigrants in the Polish labour market. The growing demand for foreign workers is in turn caused by the increasing need for labour, a consequence of the prolonged persistence of low birth rates, which are below the levels that guarantee simple population replacement, and mass emigration. Yet, the role of the demand factor in making decisions to migrate to Poland is rather minor, although its significance has increased in the last twenty-five years as a result of the operation of cross-border migration networks (Górny 2017). The prevalence of factors pushing migrants from their country of origin over those attracting them to Poland, in conjunction with their limited possibility to choose a country of destination, is especially evident in the case of the Ukrainian labour force. The migration of Ukrainians to Poland is definitely related to two sets of circumstances: the chronic economic crisis in their country of origin and limited possibilities of acquiring employment in western Europe. Had these determinants been eliminated, the number of Ukrainian labour migrants in Poland would have dropped significantly. This also means that, unlike in the case of the migration centre, the extent of migration to Poland depends less strongly on the content of Polish migration policy than on the broader determinants occurring both in migrant-sending countries and the most important destination countries.

\section{Study design}

The analyses that follow are based on data of a research project on migrations to and from Poland. In order to verify the assumption of the semi-peripheral character of Poland in relation to migration and the perception of its labour market, part of the data coming from a survey (PAPI) conducted in 2017, have been subject to secondary analysis. The survey interviewees were recruited from two groups of labour migrants: Poles employed abroad and foreigners working in Poland. Each group consisted of 100 respondents, selected through purposive sampling. Due to the limitations of the data, the analysis is to a great extent exploratory.

To qualify for the research on Polish labour migrants, a potential respondent had to be resident abroad for at least twelve months. Respondents were recruited in four centres with a significant Polish diaspora, located in the UK and Germany: London, Newcastle, Berlin and Cologne. The UK and Germany are the two most important destination countries for Poles and, obviously, outperform all the other countries in this respect. An additional criterion for the selection of respondents was professional experience abroad - at least twelve months of stay (combined) within the last two years, regardless of the form of employment or whether a person performed the work legally or not. In the sampling, special attention was paid to equal representation of the following variables:

- gender (fifty women and fifty men);

- the country where the work is being performed (fifty persons from each of the two countries);

- place of residence (twenty-five persons from each of the aforementioned cities/migration centres abroad).

Similar principles for respondent selection were implemented in the course of the research on foreigners working in Poland. The people who were selected for the survey had stayed in Poland for at least twelve months, in one of two urban centres: Warsaw or Lublin. Both of those cities stand out with respect to the (high) numbers of foreigners employed there. Additional criteria 
adopted included at least twelve months of experience of working in Poland within the last three years (whether legally or not) and at least a communicative command of Polish. The application of such a criterion was necessary because one of the topics of the survey was knowledge of the reality of the Polish labour market (especially with respect to the use of its institutions). In that group of respondents, special attention was paid to ensure equal representation of gender (fifty women and fifty men) and place of residence (fifty persons from both Warsaw and Lublin).

The sample is dominated numerically by Ukrainian citizens (eighty respondents), which reflects their substantial share in labour immigration to Poland. The other twenty were citizens of one of the following eastern European countries: Belarus, Moldova, Azerbaijan, Armenia and Georgia.

The respondents from both groups, that is, Poles in Germany and the UK, and foreigners in Poland, were asked to compare the labour markets in their country of origin and the country where they were currently working. Eleven issues (indicated in the tabular summaries later in the article) from the broad area of the functioning of the labour market were covered in the interview. In addition, questions were asked regarding the possibilities of getting support from labour market institutions as well as questions about the accessibility of social welfare benefits connected with the work performed.

\section{Results and discussion}

Views and attitudes expressed by the Polish interviewees indicate that the domestic labour market is perceived by them to be overwhelmingly inferior to the German and British markets. It confirms and reinforces the conclusions drawn by previous studies of Polish workers in these two countries, pointing to the lower attractiveness of the labour market in Poland (Drinkwater \& Garapich 2015). In comparison to those two countries, the Polish labour market is viewed by respondents as unfavourable (Table 1).

Of the several aspects of the Polish labour market examined in the study, the ability to accumulate savings is rated the lowest by respondents. This is unsurprising as it is a by-product of the perception of earnings in Poland as being relatively low. The ability to save money is actually an aspect with respect to which all the respondents pointed out the superiority of the foreign labour markets. None of them declared the superiority of Poland in this respect. A somewhat smaller perceived divergence between the Polish and the two foreign labour markets was observed with regard to the ease of finding their first job, sustainability of employment (i.e. chances of retaining or losing work) as well as the possibility of changing jobs. The vast majority of the respondents declared the superiority of Germany and the UK in all those aspects too. Only a handful of interviewees pointed to a more advantageous situation in Poland. More than half of them expressed the opinion that a wage increase is easier to obtain working abroad. Similar results were obtained by Parutis (2014) in her research on Poles and Lithuanians in the British labour market. The assessments concerning other aspects of the labour markets, especially those relating to the possibilities of reconciling work and private life, and securing employment consistent with qualifications, were more balanced. Yet, also with regard to the above aspects, the perception of both foreign labour markets as superior prevailed.

Poland also performs rather unfavourably with regard to support from institutions connected with the labour market. The institutions were understood broadly as: public institutions such as labour offices and clinics as well as different kinds of non-governmental organisations (NGOs), such as trade unions, employment agencies, charity institutions, church organisations, etc. (Table 2). All the dimensions of institutional support for people active in the labour market in Poland were assessed as weaker or less accessible than their British and German counterparts. The superiority of the UK and Germany was viewed as particularly pronounced with regard to unemployment benefits and assistance in finding a job. For both of these support aspects, an absolute majority of the respondents maintained that they were better organised in the two "old" EU countries. A somewhat smaller number of respondents emphasised the superiority of foreign institutions with regard to support to improve professional qualifications. Finally, the areas which the smallest numbers of respondents (below 40 per cent) pointed to with regard to the advantageous status of the UK and Germany were opportunities to acquire information about employees' rights and the rights of the unemployed, opportunities to get help in changing jobs, and the availability of free health care. For each of the latter three domains of activity relating to the labour market, the overall sum of the percentages of respondents expressing an opinion about the superiority of Poland, those choosing the answer "the same" and those choosing the answer "difficult to say" was equal to over 60 per cent of the total sample.

The comparison of social benefits connected with activity on the labour market is the one for which Poland performs the worst relative to the UK and Germany (Table 3). In assessing those benefits, the respondents - in approximately the same proportions - declared that these are more favourable in the UK or Germany, or they expressed indifference ("difficult to say"). This means that a simple majority of the interviewees (on average every second person interviewed) either had no knowledge of that type of benefit or showed no interest in them. Only a few people declared that such benefits were as advantageous in Poland as abroad, whereas hardly anybody expressed the opinion that they were regulated in a more advantageous way in their country of origin. Only two people declared that it was better to have an old age pension in Poland.

The same questions comparing selected aspects of the labour market, institutional support for the professionally active and the possibilities of receiving social benefits were also asked of the labour immigrants in Poland. Just like the Polish emigrants, foreigners working in Poland evaluate the labour market they currently participate in as higher than that in their country of origin. Yet, the differences in assessment are noticeably smaller than in the case of Polish emigrants to the UK and Germany. The superiority of the Polish labour market was indicated with respect to seven aspects, but for just one of them, there was a clear-cut distinction in relation to the opportunity to accumulate savings: in the respondents' view, the chances of an increase in wages as well as of retaining or changing jobs were better in Poland. At the same time, with regard to changing qualifications, or getting their first job, or especially the danger of losing a job, the superiority of Poland over their countries of origin does not seem to be significant for many respondents. By contrast, the countries of origin are assessed as being better for reconciling work and private life and for the possibility of finding legal employment as well as, to a lesser extent, of finding work consistent with qualifications and with chances for promotion (Table 4).

As in the case of evaluating the labour market, a tendency to favour Poland - but less pronounced than Polish emigrants' tendency to prefer the British and the German markets - was noticed when comparing institutions supporting professional activity. In comparison to their country of origin, the immigrants to Poland rated the assistance in finding work highest; next, in order, was the assistance in upgrading qualifications, followed by help when changing jobs. The respondents' tendency to evaluate Poland as better for providing information for professionally active people and for unemployment benefits is less manifest, even if still notable. The only aspect of the activities of institutions 
Table 1. Comparison of the labour market in Poland and the emigration country by Polish migrants in the UK and Germany (excluding respondents without work experience in Poland) (in percentages, $N=80$ )

\begin{tabular}{|c|c|c|c|c|c|}
\hline Where it is easier to: & Poland & Abroad & The same & Hard to say & Total \\
\hline find the first job & 1.3 & 70.0 & 20.0 & 8.8 & 100.0 \\
\hline remain in work & 1.3 & 43.8 & 32.5 & 22.5 & 100.0 \\
\hline change jobs & 2.5 & 78.8 & 6.3 & 12.5 & 100.0 \\
\hline lose a job & 61.3 & 2.5 & 17.5 & 18.8 & 100.0 \\
\hline work legally & 3.8 & 25.0 & 35.0 & 36.3 & 100.0 \\
\hline make savings & 0 & 97.5 & 1.3 & 1.3 & 100.0 \\
\hline be promoted & 16.3 & 22.5 & 12.5 & 48.8 & 100.0 \\
\hline get a raise & 6.3 & 57.5 & 10.0 & 26.3 & 100.0 \\
\hline reconcile work and private life & 35.0 & 37.5 & 16.3 & 11.3 & 100.0 \\
\hline work according to qualifications & 16.3 & 26.3 & 30.0 & 27.5 & 100.0 \\
\hline get new qualifications & 6.3 & 28.8 & 11.3 & 53.8 & 100.0 \\
\hline
\end{tabular}

Source: analysis of the results obtained in the study.

Table 2. Comparison of assistance from institutions related to the labour market in Poland and abroad by Polish migrants in the UK and Germany (in percentages, $N=100$ )

\begin{tabular}{|c|c|c|c|c|c|}
\hline Where it is easier to get: & Poland & Abroad & The same & Hard to say & Total \\
\hline $\begin{array}{c}\text { information on the rights of workers and the } \\
\text { unemployed }\end{array}$ & 19.0 & 37.0 & 17.0 & 27.0 & 100.0 \\
\hline $\begin{array}{c}\text { benefits for the unemployed } \\
\text { assistance in finding work }\end{array}$ & 8.0 & 56.0 & 7.0 & 29.0 & 100.0 \\
\hline help in upgrading qualifications & 7.0 & 53.0 & 14.0 & 26.0 & 100.0 \\
\hline help in changing profession & 9.0 & 43.0 & 11.0 & 36.0 & 100.0 \\
\hline free medical assistance & 8.0 & 38.0 & 31.0 & 23.0 & 100.0 \\
\hline
\end{tabular}

Source: analysis of the results obtained in the study.

Table 3. Comparison of selected social benefits in Poland and abroad by Polish migrants in the UK and Germany (in percentages, $N=100)$

\begin{tabular}{|c|c|c|c|c|c|}
\hline Where it is more profitable to apply for: & Poland & Abroad & The same & Hard to say & Total \\
\hline child benefit & 0 & 51.0 & 5.0 & 44.0 & 100.0 \\
\hline allowances for mothers/parents & 0 & 41.0 & 3.0 & 56.0 & 100.0 \\
\hline housing benefits & 0 & 55.0 & 4.0 & 41.0 & 100.0 \\
\hline pension & 2.0 & 42.0 & 3.0 & 53.0 & 100.0 \\
\hline
\end{tabular}

Source: analysis of the results obtained in the study. 
MISCELLANEA GEOGRAPHICA - REGIONAL STUDIES ON DEVELOPMENT

Vol. 24 • No. 2 • 2020 • pp. 94-103 • ISSN: 2084-6118 • DOI: 10.2478/mgrsd-2020-0005

Table 4. Comparison of Polish and native labour markets by migrants in Poland (excluding respondents without employee experience in the country of origin) (in percentages, $N=67$ )

\begin{tabular}{|c|c|c|c|c|c|}
\hline Where it is easier to: & Poland & Native country & The same & Hard to say & Total \\
\hline find the first job & 40.3 & 29.9 & 16.4 & 13.4 & 100.0 \\
\hline keep work & 40.3 & 13.4 & 34.3 & 11.9 & 100.0 \\
\hline change jobs & 53.7 & 7.5 & 20.9 & 17.9 & 100.0 \\
\hline lose a job & 23.9 & 25.4 & 32.8 & 17.9 & 100.0 \\
\hline work legally & 22.4 & 35.8 & 22.4 & 19.4 & 100.0 \\
\hline make savings & 94.0 & 1.5 & 3.0 & 1.5 & 100.0 \\
\hline be promoted & 13.4 & 19.4 & 11.9 & 55.2 & 100.0 \\
\hline get a raise & 49.3 & 4.5 & 22.4 & 23.9 & 100.0 \\
\hline combine work and private life & 25.4 & 40.3 & 25.4 & 9.0 & 100.0 \\
\hline work according to qualifications & 16.4 & 20.9 & 40.3 & 22.4 & 100.0 \\
\hline get new qualifications & 28.4 & 7.5 & 19.4 & 44.5 & 100.0 \\
\hline
\end{tabular}

Source: analysis of the results obtained in the study.

related to the labour market to receive roughly equal evaluation for their country and Poland is the possibility of receiving free health care (Table 5).

Just as in the case of labour markets and institutions supporting professional activity, the social benefits in Poland were evaluated as more advantageous by immigrants comparing them to those in their country of origin. Yet, in this dimension of the migrant situation the differences in their preferences were rather minor. Preference for the social benefits in the country of migration (Poland) was also weaker than in the case of the Poles interviewed in Germany and the UK. The latter group tended to view the German and British benefits (child benefit, employed parent benefits, housing benefits as well as the pension system) as unmatched in comparison to the same benefits in their country. It is still remarkable, however, that the foreign immigrants in Poland, more often than the Poles working abroad, chose the option "difficult to say" in response to the question about their views on social benefits. It was particularly difficult for foreigners in Poland to compare the housing benefits in Poland and in their country of origin (more than 80 per cent of the interviewees were not able to make such an assessment), as well as answer questions about working parent benefits (66 per cent of the people in the sample had such difficulties). Only slightly more than half of the people interviewed could give clear-cut answers to the questions concerning child benefit and pensions (Table 6). This suggests that their knowledge about the social benefits in the country of immigration is more limited. It can also be assumed that they rarely benefit from them. Participation in the social security system of the country of immigration is closely related to the time the person has stayed abroad. The results of other studies (Osipovič 2015) carried out in the UK demonstrate that the longer Poles stayed there the more aware they were of the philosophy of the British welfare state and the more they knew about its institutions.

When comparing the opinions of respondents from each group studied, it is easy to see that the differences in the assessment of the conditions and benefits of working in the country of origin as opposed to working in the country of migration are, in virtually all aspects, smaller for foreigners working in Poland than for Poles in the UK and Germany. Therefore, the results of the above exploration suggest that the distance between the Polish and the British/German labour markets is larger than between the former and the labour markets of the countries that the immigrants in Poland come from. This fits the conclusions drawn by previous studies on the evaluation of the institutions of the Polish welfare state by selected groups of foreigners. While for Britons and Spaniards social benefits offered in Poland had no attracting power, what attracted the Ukrainians was the transparency of social institutions (health care among them) as well as the relative freedom from corruption (Andrejuk 2017).

The source of such diversity of opinions among the immigrants studied lies perhaps in their varying personal experience of workers' cross-country situations. The context of that experience also includes each member of the group's specific position in the labour market. The most important dimension of this position, and the most significant factor differentiating both groups, is the legality of employment. A significantly greater share of the immigrants in Poland are employed illegally. Only a little more than half of them declared that they were working under an employment contract (55 per cent, while 42 per cent were under indefinite duration contracts). The situation of the Polish group working in the west was definitely more advantageous - almost all of them (92 per cent) were employed under an indefinite duration contract. The above substantial divergence regarding the legality of work brings about further differences: it determines how deeply rooted in the local labour market the foreign workers are. It also translates into knowledge of workers' rights and of the scope of protection against unfair practices by employers, the possibility of using the services offered by official institutions, and access to social benefits as well as to a higher level of income. Taking all these factors into consideration explains, to a certain extent, the disparity in the subjectively perceived distance between the labour markets mentioned. In other words, it throws new light on the comparison of the Polish labour market with labour markets in the countries of origin of the immigrants in Poland. It can be assumed that with a larger scale of legal 
Table 5. Comparison of assistance from institutions related to the labour market in Poland and in the country of origin by migrants in Poland (in percentages, $N=100$ )

\begin{tabular}{|c|c|c|c|c|c|}
\hline Where it is easier to get: & Poland & Native country & The same & Hard to say & Total \\
\hline $\begin{array}{c}\text { information on the rights of workers } \\
\text { and the unemployed }\end{array}$ & 29.0 & 18.0 & 25.0 & 28.0 & 100.0 \\
\hline benefits for the unemployed & 36.0 & 25.0 & 16.0 & 23.0 & 100.0 \\
\hline assistance in finding work & 38.0 & 8.0 & 29.0 & 25.0 & 100.0 \\
\hline help in upgrading qualifications & 29.0 & 11.0 & 18.0 & 42.0 & 100.0 \\
\hline help in changing profession & 24.0 & 10.0 & 16.0 & 50.0 & 100.0 \\
\hline free medical assistance & 17.0 & 17.0 & 29.0 & 37.0 & 100.0 \\
\hline
\end{tabular}

Source: analysis of the results obtained in the study.

Table 6. Comparison of selected social benefits in Poland and the country of origin by migrants in Poland (in percentages, $N=100)$

\begin{tabular}{|c|c|c|c|c|c|}
\hline Where it is more profitable to apply for: & Poland & Native country & The same & Hard to say & Total \\
\hline child benefit & 32.0 & 21.0 & 2.0 & 45.0 & 100.0 \\
\hline allowances for mothers/parents & 20.0 & 12.0 & 2.0 & 66.0 & 100.0 \\
\hline housing benefits & 7.0 & 6.0 & 5.0 & 82.0 & 100.0 \\
\hline pension & 24.0 & 18.0 & 12.0 & 46.0 & 100.0 \\
\hline
\end{tabular}

Source: analysis of the results obtained in the study.

employment of foreigners in Poland, their assessment of the Polish labour market would be more favourable and more similar to the evaluation of labour markets in the UK and Germany made by the Polish respondents.

In the context of the dynamics in changing labour markets, it is also interesting how respondents perceive the future of these markets in the country of origin and in the country of emigration. A comparison between the projections made by Polish immigrants in the UK and Germany and those made by foreigners employed in Poland discloses significant differences between the two groups of people seeking employment abroad and being in a similar situation of emigration. The Poles interviewed perceive the future of their country in a much more optimistic way. No more than one-sixth of them (only 16 per cent) expect that the present-day differences between Poland and the UK/Germany, unfavourable to Poland, will persist or even increase. By contrast, among the group of foreigners working in Poland nearly two-thirds (64 per cent) expressed the opinion that the position of their country in relation to Poland will not change or, a more prevailing opinion (expressed by nearly half of the respondents), that it will increase. On the other hand, nearly a fifth (19 per cent) of the Polish respondents and only 2 per cent of the foreigners working in Poland expect that the discrepancies between their country of origin and the country they migrated to will level out.

Translating the results of the research into the language of metaphor we can acknowledge that the most likely scenario for Poland is either "leaving the periphery" (in the perspective adopted by Polish emigrants) or strengthening the centrality (or quasicentrality) in at least the regional dimension (in the perspective adopted by foreigners seeking employment in Poland).

\section{Conclusion}

The uniqueness of migration in Poland rests on the fact that it is simultaneously a migrant-sending and migrant-receiving country. While remaining a country of emigration, Poland, relatively soon after the onset of the systemic transformation, and then after accession to the EU, became a country of destination for numerous groups of migrants, especially temporary and seasonal.

From the perspective of the centre-periphery theory, this kind of heterogeneity of functions served within a definite spatial system fits with the characteristics of semi-peripheral areas. According to this concept, the semi-peripheries are characterised by a medium-sized concentration of resources, which also defines the roles fulfilled by this kind of area. These roles are not as significant for the functioning of the whole system as are the roles played by the central areas; nevertheless, the semi-peripheries are preponderant in significance over the classic peripheries, and in some aspects they can fulfil quasi-central functions for those peripheries and thereby compete in this respect with the core areas (Wallerstein 1984).

If we adapt the descriptive categories classifying space in terms of the core-periphery theory to the push-pull theory explaining the mechanisms of migration (Lee 1966), it should be assumed that the areas defined as migration semi-peripheries act as a source of multidirectional (often contradictory) stimuli, incentivising both departures and arrivals of migrants. This is due to the intermediate character of factors influencing migration decisions in those areas. Such migration settings are less favourable than the countries of the migration centre but, at the same time, more favourable than those of the migration periphery. This intermediate condition encompasses both the objective 
MISCELLANEA GEOGRAPHICA - REGIONAL STUDIES ON DEVELOPMENT

Vol. $24 \cdot$ No. $2 \cdot 2020 \cdot$ pp. 94-103 • ISSN: 2084-6118 • DOI: 10.2478/mgrsd-2020-0005

Table 7. Forecasts regarding the economic situation in the native country and the country of emigration by migrants (in percentages, $N=100+100)$

\begin{tabular}{|c|c|c|}
\hline $\begin{array}{c}\text { Differences between native country and the country of } \\
\text { economic emigration in 10 years ... }\end{array}$ & $\begin{array}{c}\text { Poles in the UK and } \\
\text { Germany }\end{array}$ & Immigrants in Poland \\
\hline will remain unchanged & 10.0 & 16.0 \\
\hline will increase & 6.0 & 48.0 \\
\hline will decrease & 14.0 & 2.0 \\
\hline will even out & 19.0 & 25.0 \\
\hline hard to say & 51.0 & 100.0 \\
\hline Total & 100.0 & 2.0 \\
\hline
\end{tabular}

Source: analysis of the results obtained in the study.

character of various solutions and the level of development of particular institutions of the labour market and social security, in addition to the push-pull factors of the non-material political and cultural character and the subjective evaluations made by potential migrants, resulting from their knowledge and experience.

The results of the analyses presented in this study demonstrate explicitly the in-between migration attractiveness of Poland with regard to the aspects chosen (and of key significance) in the functioning of both the labour market and the social security institutions. According to the views expressed by the Polish respondents living in the UK and Germany, all the institutions mentioned are far better organised there than in Poland. In the same vein, foreigners working in Poland look favourably at the labour market and social security in that country when comparing it to their native country. Thus, adopting the above perspective of diverse worker experiences of the immigrants studied, some qualities of both the migration peripheries and the migration core can be ascribed to Poland.

Poland constitutes a periphery for its own citizens emigrating in search of work. This kind of evaluation made by them in international migration is, at the same time, a confirmation (evident also on the basis of the statistical data regarding the net migration rate) of the undoubted core character of the western European countries touched upon by the study. At the same time, Poland plays the role of the specific sub-core for the migrants from less-developed countries, especially Ukraine. The peripheral role in relation to Poland of the latter countries in the system of global migrations is also proved by the lack of migration in the opposite direction - Polish citizens do not emigrate (in any statistically noticeable numbers) to the countries from which the labour migrants come to Poland. This, in turn, puts the latter countries in a position of a migration periphery, both from the point of view of migration cores and migration semi-peripheries.

From the perspective of traditional migration studies, the semi-peripheral role of Poland in global migration could perhaps be explained with reference to the transitory phase of migration transformation in which the country still remains. As a consequence of generally positive economic and political changes initiated after the collapse of communism, Poland is no longer just a classical migrant-sending country. Yet, the longlasting tendency of the increasing number of immigrants has not led to the transformation of Poland into a typical migrant-receiving country, as that tendency was not accompanied by a one-way decrease of Polish citizens emigrating. Moreover, Poland is still not attractive as a migration destination for residents of developed countries. The incomplete migration transition of Poland is statistically confirmed by the persistent negative indicator of the balance of external migration flows and the fact that its current values are near zero. The constant improvement of that index is evidence of the increasing migration significance of Poland in terms of the possibilities created for immigrants by the Polish labour market.

Recognition of Poland's migratory semi-peripherality should be the starting point for further research related to the following questions. What exactly is this "semi-peripheral" status, how does it differ from the "semi-peripheral" and "peripheral" statuses of other countries in Central and Eastern Europe? What factors cause the migratory semi-peripherality of Poland and which of them should be considered key? What actions should Poland take (especially which migration policy should be followed) in order to evolve in the area of international migration towards the centre, and avoid the risk of degradation towards the periphery?

\section{Acknowledgments}

This article is an output of the research project In Search of Labour Market Security. Migration to and from Poland and the Attractiveness of the Polish Labour Market, financed by the National Centre of Science (contract UMO-2014/15/B/ HS5/01148). The author is grateful to Maciej Duszczyk, Kamil Matuszczyk and Maciej Górecki for their helpful comments.

\section{ORCID}

Cezary Żołędowski (1) https://orcid.org/0000-0001-6262-8002 


\section{References}

Andrejuk, K 2017, 'Znaczenie polskiej sfery welfare dla imigrantów' ['The importance of the Polish welfare sphere for immigrants'], Studia BAS, vol. 50, no. 2, pp. 107-128.

Burrell, K 2009, Polish migrants to the UK in the "new" European Union after 2004, Routledge, London.

Ciupijus, Z 2011, 'Mobile central Europeans in Britain: successful European Union citizens and disadvantaged labour migrants?' Work, Employment and Society, vol. 25, no. 3, pp. 540-550.

Drinkwater, S \& Garapich, MP 2015, 'Migration strategies of Polish migrants: Do they have any at all?', Journal of Ethnic and Migration Studies, vol. 41, no. 12, pp. 1909-1931.

Duszczyk, M \& Matuszczyk, K 2018 'The employment of foreigners in Poland and the labour market situation', Central and Eastern European Migration Review, vol. 7, no. 2, pp. 53-68.

Główny Urząd Statystyczny 2018, Informacja o rozmiarach $i$ kierunkach czasowej emigracji z Polski w latach 2004-2017 [Information on the size and directions of temporaryemigration from Poland in 2004-2017]. Available from: <https://stat. gov.pl/obszary tematyczne/ludnosc/migracje-zagraniczneludnosci/informacja-o-rozmiarach-i-kierunkach-czasowejemigracji-z-polski-w-latach-2004-2017,2,11.html>. [25 March 2019].

Główny Urząd Statystyczny 2017, Rocznik demograficzny [Demographic Yearbook], Warszawa.

Gois, P \& Marques, JS 2009, 'Portugal as a semi-peripheral country in the Global Migration System', International Migration, vol. 47, no. 3, pp. 21-50.

Górny, A 2017, 'All circular but different: Variation in patterns of Ukraine to Poland migration', Population, Space and Place, vol. 23, no. 8. Available from: <https://onlinelibrary.wiley. com/doi/full/10.1002/psp.2074>. [6 November 2018].

Górny, A \& Kaczmarczyk, P 2018, 'A known but uncertain path: The role of foreign labour in Polish agriculture', Journal of Rural Studies, vol. 64, pp. 177-188.

Hannerz, U 1998, Transnational connections: culture, people, places, Routledge, London- New York.

Iglicka, K 2002, 'Poland: Between geopolitical shifts and emerging migratory patterns', International Journal of Population Geography, vol. 8, no. 2, pp. 153-164.

Janicka, A \& Kaczmarczyk P 2016, 'Mobilities in the crisis and post-crisis times: migration strategies of Poles on the EU labour market', Journal of Ethnic and Migration Studies, vol. 42, no. 10 , pp. 1693-1710.

Kritz, MM \& Zlotnik, H 1992, 'Global interactions: migration systems, processes and policies', in International Migration Systems. A Global Approach, eds MM Kritz, LL Lim \& H Zlotnik, Clarendon Press, Oxford, pp. 1-16.

Lee, ES 1966, 'A theory of migration', Demography, vol. 3, no. 1, pp. 47-57.

Ministerstwo Rodziny, Pracy i Polityki Społecznej 2018, Cudzoziemcy pracujący w Polsce [Foreigners working in Poland]. Available from: <https://www.mpips.gov.pl/analizyi-raporty/cudzoziemcy-pracujacy-w-polsce-statystyki/>. [6 November 2018].

Okólski, M 2010, 'Will Poland become a country of immigration?', Studia Migracyjne-Przegląd Polonijny, vol. 36, no. 4, pp. 131-157.

The Organisation for Economic Co-operation and Development (OECD) 2018, International Migration Outlook 2018. Available from: <http://www.oecd.org/migration/international-migrationoutlook-1999124x.htm>. [9 October 2018].
Osipovič, D 2015, 'Conceptualisations of Welfare Deservingness by Polish Migrants in the UK', Journal of Social Policy, vol. 44, no. 4, pp.729-746.

Parutis, V 2014, "Economic Migrants" or "Middling Transnationals"? East European Migrants' Experiences of work in the UK', International Migration, vol. 52, no. 1, pp. 36-55.

Reddaway, WF, Penson, JH, Halecki, O \& Dyboski, R (eds) 2016, The Cambridge history of Poland. From Augustus Il to Pilsudski (1697-1935),Cambridge University Press, Cambridge.

Rokkan, S. \& Urwin, D 1983, Economy, territory, identity: politics of West European peripheries, Sage Publications, London.

Stark, O, Micevska, M \& Mycielski, J 2009, 'Relative poverty as a determinant of migration: Evidence from Poland', Economics Letters, no. 103, pp. 119-122.

Tyrowicz, J, Kaczmarczyk, P \& Górny, A 2017, 'The influence of economic migration on the Polish economy, mBank-CASE Seminar Proceedings. Available from: <http://www.caseresearch.eu/files/?id_plik=5315>. [8 December 2018].

Urząd ds. Cudzoziemców 2019, Legalizacja pobytu w I połowie 2019 r. [Legalization of stay in the first half of 2019]. Available from: <https://udsc.gov.pl/legalizacja-pobytu-w-i-polowie2019-r/>. [28 March 2019].

Wallerstein, I 1974, The modern World-System I: Capitalist agriculture and the origins of the European World-economy in the sixteenth century, Academic Press, New York.

Wallerstein, I 1984, The politics of the World-Economy. The states, the movements and the civilizations, Cambridge University Press, Cambridge.

Winders, J 2014, 'New immigrant destinations in global context', International Migration Review, vol. 48, no. s1, pp. 149-179.

Zakład Ubezpieczeń Społecznych 2018, Ubezpieczenia emerytalne $i$ rentowe. Cudzoziemcy [Retirement and disability insurance. Foreigners]. Available from: <http://psz. zus.pl/kategorie/ubezpieczeni/ubezpieczenia-emerytalne-irentowe>. [5 May 2019].

Zarycki, T (ed.) 2016, Polska jako peryferie [Poland as a periphery], Wydawnictwo Naukowe Scholar, Warszawa. 